\title{
ULASAN IMPLEMENTASI SEBUAH BUSINESS MODEL DI PT. SAKTI PERSADA RAYA
}

\author{
Adeline Agoes \\ Jurusan Hotel Management, Fakultas Ekonomi dan Komunikasi, BINUS University \\ Jln. K.H. Syahdan No. 9, Palmerah, Jakarta Barat 11480 \\ adeline.agoes@ymail.com
}

\begin{abstract}
In this economic world of business in Indonesia, Jakarta is one of the cities that supports the industry which now is growing quite fast with the development of many establishments. However, it is unfortunate that some of those establishments could not survive long facing the competition. One of the reasons that might cause that to happen is because of the lack of preparation in the Business Model. This journal will briefly discuss what are the definition and the importance of a Business Model which will be described in more detail with a real Business Model implemented by PT. SAKTI PERSADA RAYA.
\end{abstract}

Keywords: business model

\begin{abstract}
ABSTRAK
Dalam dunia industri bisnis di Indonesia sekarang ini, Jakarta merupakan salah satu kota penunjang yang tumbuh pesat dengan pembangunan dan pengembangan berbagai macam usaha. Namun demikian, cukup banyak juga usaha-usaha yang tidak dapat bertahan lama menghadapi persaingan industri yang mana salah satunya dapat disebabkan oleh tidak terdapatnya kesiapan sebuah Business Model yang seyogyanya terencana dengan baik. Di dalam penulisan ini akan diulas secara ringkas apa arti dan pentingnya sebuah Business Model yang akan dideskripsikan secara lebih detil dengan sebuah Business Model yang sudah diimplementasikan oleh PT. SAKTI PERSADA RAYA.
\end{abstract}

Kata kunci: business model 


\section{PENDAHULUAN}

Indonesia merupakan sebuah negara kepulauan yang kaya akan sumber daya wisata sekaligus juga ramai oleh industri bisnis dan ekonomi. Jakarta, tentunya merupakan kota yang saat ini tumbuh dengan pesat sebagai kota penunjang berlangsungnya industri bisnis di Indonesia. Selain dengan padatnya lalu lintas, pertumbuhan tersebut ditandai juga dengan semakin maraknya perkembangan tempat usaha seperti outlet, restaurant dan hotel. Hampir setiap hari, jumlah kendaraan yang mempergunakan lalu lintas di Jakarta terlihat semakin padat. Sayangnya, cukup banyak juga perusahaan yang tidak bertahan lama berada di industri perekonomian sekarang ini.

Tumbangnya sebuah perusahaan, salah satunya dapat disebabkan oleh tidak terdapatnya kesiapan sebuah Business Model yang seyogyanya terencana dengan baik. Nesheim (2009) mengatakan "In today's market for startup investors, you cannot attract them without a great business model”. Lalu apa itu sebuah Business Model? Business Model adalah sebuah sistem yang dapat membuat perusahaan tumbuh dan berkembang secara berkelanjutan. "A business model is a summation of the core business decisions and trade-offs employed by a company to earn profits; a business model describes how an enterprise proposes to make money" (Essentials, 2005)

Beberapa teori di atas mencerminkan bahwa untuk membangun sebuah perusahaan dari awal, sangat dianjurkan untuk membuat sebuah Business Model terlebih dahulu, dimana sebuah perusahaan dapat mendesripsikan rencana untuk menghasilkan uang atau keuntungan, produk apa yang akan ditawarkan, bagaimana rencana pencapaian pasar, dan sebagainya. Hal ini detekankan juga oleh definisi yang disampaikan oleh Danielle McInnis di dalam blog-nya, "A business model is a framework, the engine room that you use to run and have visibility to your business. It answers the questions for all business decisions that you make. How do you intend to make money and what model will you use to sustain your business.” (McInnis, 2011)

Seperti yang telah dikatakan, di Jakarta sekarang ini banyak tumbuh perusahaan-perusahaan yang bergerak dalam berbagai bidang. Namun demikian, tidak semua perusahaan yang dibangun merupakan perusahaan besar yang dapat terlihat secara langsung pengembangannya. PT. SAKTI PERSADA RAYA adalah salah satu contohnya. Perusahaan yang bergerak dalam bidang komoditi beras ini, seperti perusahaan-perusahaan lainnya, mencoba untuk menghasilkan perputaran ekonomi yang menguntungkan. Pada pembahasan sekarang, penulis akan menggambarkan Business Model yang diadopsi oleh PT. SAKTI PERSADA RAYA dalam pelaksanaan usahanya.

\section{PEMBAHASAN}

\section{Business Model PT. Sakti Persada Raya}

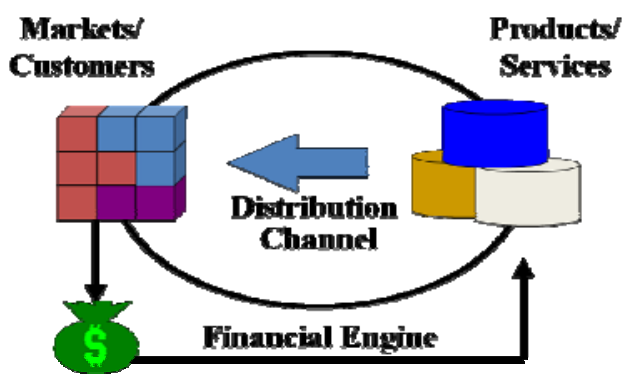

Gambar 1 Skema Business Model yang diadopsi oleh PT. SAKTI PERSADA RAYA 


\section{Products / Services}

\section{Nilai dari Produk / Jasa}

PT. SAKTI PERSADA RAYA merupakan sebuah perusahaan yang bergerak dalam bidang perdagangan beras di Indonesia. Pada dasarnya produk beras yang ditawarkan oleh perusahaan ini tidak jauh berbeda dengan produk beras lainnya, namun demikian PT. Sakti Persada Raya memiliki nilai yang dianut oleh organisasi untuk memproduksi beras alami tanpa bahan-bahan kimia yang terlibat dalam prosesnya. Hal ini berawal dari pengamatan para pendiri perusahaan ini terhadap distribusi beras yang tersebar di Indonesia sekarang.

Mereka melihat bahwa sebagian besar produk beras yang sampai pada masyarakat memiliki kualitas yang tidak baik bahkan beberapa diantaranya telah tercampur oleh bahan kimia pemutih yang biasa dipakai untuk produk tekstil. Dengan kondisi tersebut maka para pengusaha ini tergerak untuk menghasilkan produk kebutuhan masyarakat yang sepenuhnya murni dan tidak membahayakan kesehatan. Selain itu, PT. SAKTI PERSADA RAYA juga dapat menghasilkan produk turunan dari sisa penggilingan beras seperti makanan ternak dan tepung untuk kemudian dimanfaatkan oleh industri yang terkait.

\section{Infrastruktur}

\section{Pabrik dan Lahan Produksi}

Untuk dapat mengakomodir demand terhadap ketersediaan beras yang cukup tinggi, tentu perlu terdapat lahan produksi dan pabrik penggilingan beras dengan fasilitas yang mendukung. Biasanya lokasi penggilingan beras dibangun dekat dengan aksesnya terhadap supply bahan mentah yang dalam hal ini adalah gabah. Maka dari itu sebagian besar lahan produksi beras dibangun dekat dengan pesawahan. Walaupun demikian, terdapat juga kemungkinan lain untuk menentukan lokasi pabrik sebagai lahan produksi, diantaranya adalah pada lokasi yang dekat dengan akses distribusi. Biasanya pabrik-pabrik ini dibangun di daerah pinggiran kota yang dekat dengan pasar dan vendorvendor lain yang potensial.

Pabrik dan lahan produksi PT. SAKTI PERSADA RAYA terdapat 1 buah di daerah sekitar Jawa Tengah dan 4 buah di daerah-daerah sekitar Karawang. Di Jawa Tengah pabrik penggilingan beras dibangun sangat dekat dengan lokasi supplier gabah yang diantaranya para petani yang dibantu perusahaan ini untuk mengelola pesawahan yang ada. Sedangkan di Karawang pabrik-pabrik penggilingan beras, selain juga tentu dekat dengan supplier, didirikan dengan maksud untuk memperpendek akses terhadap para vendor yang terutama adalah para penjual beras di Pasar Cilingcing. Dengan demikian, biaya yang dikeluarkan seperti untuk transportasi akan dapat dikurangi.

Berbeda dengan para pesaingnya, PT. SAKTI PERSADA RAYA memiliki strategi untuk mendirikan pabrik yang sederhana tetapi dengan jumlah yang tersebar di beberapa wilayah. Menurut pengamatan Yanee Lasahido, salah satu pendiri perusahaan ini, biaya yang dikeluarkan jauh lebih rendah apabila dibandingkan dengan pembangunan satu atau dua buah pabrik besar. Selain itu Yanee juga mengatakan bahwa jumlah dan kualitas produksi yang dihasilkan tidak akan kalah bersaing.

\section{Mesin Penggiling}

Seperti halnya pabrik dan lahan produksi beras, mesin-mesin yang dipergunakan dalam penggilingan gabah adalah mesin-mesin tradisional yang dapat dioperasikan oleh tenaga kerja umum. Dengan menerapkan strategi seperti ini, PT. SAKTI PERSADA RAYA tidak perlu menanamkan investasi yang terlalu besar namun akan dapat mendapatkan hasil produksi yang bersaing dengan 
perusahaan produksi dan distribusi beras yang lainnya. Mesin penggilingan modern perlu didatangkan dari negara-negara luar, maka dari itu biaya investasi yang dimaksud, termasuk di dalamnya adalah biaya import dan biaya maintenance atau pemeliharaan yang tinggi karena selain memerlukan tenaga ahli dalam pengoperasiannya, mesin jenis modern ini pun perlu dipelihara oleh mekanik khusus. Mesin penggilingan beras yang dimiliki oleh PT. SAKTI PERSADA RAYA di 5 daerah yang telah disebutkan mampu memproduksi beras dengan kapasitas maksimum 120 ton per bulannya.

\section{Mesin Pengering}

Usaha yang dijalankan oleh PT. SAKTI PERSADA RAYA merupakan sebuah usaha yang sangat tergantung dari kualitas bahan mentah yang akan diproses. Gabah yang menjadi sumber dari pelaksanaan usaha ini merupakan bahan baku yang rawan terhadap cuaca. Gabah yang bagus, selain dilihat dari bibitnya dapat dilihat dari kadar kematangan dan tingkat kekeringannya. Oleh karena itu, untuk menjaga kelangsungan produksi pada saat cuaca hujan, perusahaan ini memerlukan unit-unit mesin pengering gabah. Tidak banyak perusahaan yang memiliki mesin seperti ini, untuk itu investasi yang ditanamkan oleh PT. SAKTI PERSADA RAYA untuk mesin pengering gabah merupakan investasi yang penting sebagai salah satu cara untuk menjaga stabilisasi penjualan.

\section{Aset pendukung}

\section{Alat Transportasi}

Tanpa alat transportasi yang sesuai, pelaksanaan teknis delivery beras yang telah diproduksi pada market tentu tidak akan dapat terjadi. Maka dari itu PT. SAKTI PERSADA RAYA memiliki beberapa unit truk dengan skala besar untuk mengantar produk pada market.

\section{Markets / Customers}

\section{Pelanggan}

Dipaparkan oleh Yanee Lasahido, bahwa menurut pengamatannya, demand untuk beras di Indonesia saja mencapai lebih dari 250 juta ton per tahun. Dengan fakta seperti ini, dapat dikatakan bahwa memang hampir seluruh penduduk Indonesia mengkonsumsi beras sebagai bahan pannya sharihari. Namun demikian PT. SAKTI PERSADA RAYA lebih berhati-hati dalam memilih target konsumen, dilihat dari daya belinya.

\section{Pasar Tradisional}

Pasar tradisional merupakan target konsumen nomor satu yang menjadi sasaran PT. SAKTI PERSADA RAYA karena volume pembeliannya yang sangat besar. Berdasarkan pengalaman, pembelian yang dilakukan oleh pasar tradisional mencapai sekitar $70 \%$ dari produksi beras yang dipenuhi oleh PT. SAKTI PERSADA RAYA. Sampai saat ini, para pedagang beras yang melaksanakan usahanya di pasar masih terus berkembang.

Untuk dapat mendapatkan harga jual yang cukup tinggi, PT. SAKTI PERSADA RAYA memiliki strategi khusus dalam menentukan waktu penjualan ketika harga pasaran beras sedang meningkat. Harga jual beras di pasaran juga tergolong fluktuatif, jadi penjualan yang tinggi sangat tergantung dari keahlian perusahaan ini dalam melihat situasi pasar. 


\section{Industri Langsung}

Industri langsung yang dimaksud disini adalah perusahaan-perusahaan yang membutuhkan bahan baku beras dalam pelaksanaan usahanya. Industri yang sudah dapat diraih oleh PT. SAKTI PERSADA RAYA diantaranya adalah perusahaan bahan makanan instan seperti Indofood, dsb. Selain itu PT. SAKTI PERSADA RAYA juga merambah industri Horeca atau Hotel, Restaurant and Café.

Untuk supply-nya pada Industri Horeca, PT. SAKTI PERSADA RAYA menerapkan harga khusus untuk beras yang kualitasnya terpilih. Biasanya harga jual beras disesuaikan dengan harga penjualan makanan jadi yang disediakan oleh industri Horeca setelah pajak dan biaya tambahan lain. Hal ini dapat dilakukan karena kualifikasi yang diterapkan oleh industri memiliki standar yang lebih tinggi dibandingkan dengan konsumen yang lain.Volume penjualan yang didapat dari industri mencapai sekitar 20\% dari total produksi yang dapat dipenuhi oleh PT. SAKTI PERSADA RAYA. Dapat dilihat bahwa perbedaan demand dengan target pasar sebelumnya cukup tinggi.

\section{Industri Rumah Tangga}

Selain dari pasar tradisional, industri rumah tangga atau household vendors mendapatkan supply berasnya dari supermarket atau kios-kios bahan makanan lain. Namun dalam hal ini, PT. SAKTI PERSADA RAYA lebih memilih supermarket-supermarket ternama yang ingin memiliki produk home-brand untuk kemudian dijual di perusahaannya sendiri.

PT. SAKTI PERSADA RAYA dapat memenuhi supply beras yang dibutuhkan tanpa perlu mengeluarkan biaya-biaya lain seperti packing dan sebagainya. Volume pembelian yang dilakukan oleh pasar jenis ini memang tidak terlalu tinggi, hanya 4\% - 7\% dari total volume produksi, namun PT. SAKTI PERSADA RAYA dapat lebih leluasa meningkatkan harga jualnya.

\section{Industri Terkait}

Dikatakan sebagai industri terkait karena pasar jenis ini diraih oleh PT. SAKTI PERSADA RAYA sebagai konsumen untuk produk-produk turunan dari beras. Sangat menguntungkan apabila konsumen ini dapat terus di-supply oleh PT. SAKTI PERSADA RAYA karena pada dasarnya produk yang dibeli merupakan 'waste' atau sisa dari hasil penggilingan beras yang tidak dapat dijual sebagai bahan konsumsi yang utuh. 'Waste' yang dihasilkan dari proses penggilingan beras umumnya cukup tinggi, mencapai hingga 20\% - 30\% dari 100\% gabah.

Seperti yang sebelumnya telah diulas, produk-produk yang dimaksud disini adalah seperti produk tepung beras dan atau bahan makanan ternak yang diolah dari beras atau biji gabah yang sudah hancur. PT. SAKTI PERSADA RAYA dapat menjual produk-produk ini pada perusahaan seperti Bogasari atau vendor-vendor lokal di berbagai daerah. Dengan demikian, dapat dikatakan bahwa seluruh produksi penggilingan beras perusahaan ini memiliki pasar yang potensial.

\section{Persaingan}

Pada dasarnya PT. SAKTI PERSADA RAYA merupakan sebuah perusahaan yang cukup berani untuk terjun ke dalam industri ini. Ketika diwawancara, Yanee Lasahido juga mengatakan bahwa saingan yang dihadapi perusahaan ini adalah perusahaan-perusahaan lain yang sudah berkembang bahkan menjalankan bisnisnya selama belasan hingga puluhan tahun seperti Sinar Mas Group, dsb.

Tentunya para pendiri PT. SAKTI PERSADA RAYA memiliki perhitungan yang matang hingga mampu memutuskan untuk tetap menjalankan bisnisnya. Pertimbangan yang utama sebelum perusahaan ini didirikan adalah banyaknya demand yang potensial untuk dipenuhi. Maka dari itu, 
persaingan yang ada tentunya akan dapat selalu dihadapi. Strategi yang diterapkan oleh PT. SAKTI PERSADA RAYA dalam usahanya adalah mencari berbagai titik competitive advantages yang dapat ditawarkan kepada konsumen, sekaligus memberikan keuntungan melalui cost effectiveness dan profit margin yang lebih tinggi untuk perusahaan.

Competitive advantages yang dimaksud diantaranya adalah penggalian teknologi yang dapat diadaptasikan secara teknis dalam operasional perusahaan seperti perpendekan proses produksi atau pencarian alternatif bahan baku seperti proses produksi beras kualitas tinggi dari beras memiliki kualitas lebih rendah.

\section{Distribution Channel}

\section{Distribusi}

Banyak perusahaan yang bergerak dalam industri serupa dengan PT. SAKTI PERSADA RAYA, tetapi banyak juga dari perusahaan-perusahaan ini yang hanya memilih untuk berperan sebagai distributornya tanpa harus melibatkan diri dalam proses produksi. Semakin panjang jalur distribusi yang terlibat, maka secara logis dapat kita lihat bahwa semakin tinggi juga biaya yang diperlukan. Oleh karena itu harga akan semakin tinggi. Distribution channel yang terlibat dengan kelangsungan usaha PT. SAKTI PERSADA RAYA terdiri dari berbagai jenis perusahaan. PT. SAKTI PERSADA RAYA tidak menjual hasil produksinya langsung kepada end consumer atau pelanggan terakhir, melainkan melalui berbagai vendor yang tersebar di beberapa daerah.

Beberapa perusahaan yang menjadi target konsumen juga sebenarnya berperan sekaligus sebagai distribution channel. Sebagai contoh supermarket atau kios penyedia bahan baku makanan yang tidak mampu untuk membuat home-brand production dapat dimanfaatkan sebagai agen penjualan beras. Namun demikian PT. SAKTI PERSADA RAYA tidak ingin memiliki terlalu banyak agen distribusi seperti ini, karena walaupun semakin panjang distribution channel harga jual dapat menjadi semakin tinggi, namun berdasarkan penelitian yang telah dilakukan, pembelian melalui supermarket atau kios sebagian besar dilakukan oleh rumah tangga yang volumenya sangat sedikit apabila dibandingkan dengan kapasitas produksi yang dimiliki perusahaan ini.

\section{Pemasaran}

PT. SAKTI PERSADA RAYA melakukan pemasaran untuk memperkenalkan produk berasnya hanya melalui networking dengan industri atau perusahaan yang menjadi target konsumen. Diluar itu, perusahaan ini belum merasa perlu untuk mengadakan promosi sebagai instrumen dari penjualan dalam meraih brand awareness pasar. Secara teoritis, mungkin dapat dikatakan bahwa metode marketing seperti ini adalah Business to Business Marketing.

Satu hal yang dapat dibanggakan oleh perusahaan ini adalah bahwa PT. SAKTI PERSADA RAYA telah memiliki hak paten dari merk-merk produk berasnya. Yanee Lasahido mengemukakan bahwa tidak banyak perusahaan yang melakukan hal ini, namun PT. SAKTI PERSADA RAYA merasa perlu untuk menjaga konsistensi kualitas produk dan kepercayaan konsumen.

\section{Financial Engine}

Pemicu Biaya (e.g. production, promotion, maintenance, etc.)

Dalam berbagai jenis usaha, tentunya banyak terdapat berbagai biaya yang perlu dikeluarkan untuk kelangsungan bisnis yang dilakukan. Berikut ini merupakan beberapa jenis biaya yang menonjol dalam operasi bisnis PT. SAKTI PERSADA RAYA: 


\section{Biaya Penelitian dan Pengembangan}

Biaya ini dikeluarkan untuk mencari dan menentukan competitive advantages yang dimiliki oleh PT. SAKTI PERSADA RAYA, juga untuk mencari teknologi terbaru yang dapat diterapkan dalam operasional perusahaan untuk mendapatkan cost effectiveness dan profit margin yang lebih tinggi.

\section{Biaya Produksi}

Biaya yang dikeluarkan untuk proses penggilingan beras dari bahan baku mentah hingga menjadi beras yang siap dijual. Biaya produksi biasanya akan menjadi lebih tinggi apabila kualitas bahan baku gabah tidak sesuai dengan yang sudah ditentukan, karena memerlukan proses yang lebih panjang hingga dapat digiling menjadi beras.

\section{Biaya Pemeliharaan}

Biaya yang dikeluarkan untuk perawatan infrastruktur serta mesin-mesin besar yang dimiliki oleh PT. SAKTI PERSADA RAYA. Selain itu tentu ada biaya perawatan alat transportasi yang sering dipergunakan untuk distribusi produk beras pada konsumen. Maintenance atau pemeliharaan seperti pada perusahaan lain tentu memakan biaya yang cukup tinggi.

\section{Biaya Transportasi}

PT. SAKTI PERSADA RAYA perlu mengantar produk berasnya pada target konsumen, maka dari itu tentu terdapat biaya transportasi yang cukup signifikan melihat kapasitas produksi yang cukup besar dan konsumen yang tersebar di berbagai daerah.

\section{Struktur Modal Usaha}

Modal usaha yang menjadi bakal dari usaha PT. SAKTI PERSADA RAYA terdiri dari dana sendiri yang dibagi dari proporsi yang seimbang untuk 3 orang pendiri perusahaan dan sisanya tentu dari pinjaman pada pihak ketiga.

\section{Penjualan Potensial}

Secara kasar dapat diperhitungkan bahwa penjualan potensial yang bisa diraih oleh PT. SAKTI PERSADA RAYA merupakan akumulasi dari kapasitas produksi dengan harga jual rata-rata setiap bulannya. Dari 5 buah pabrik yang dimiliki oleh perusahaan ini, setiap pabrik mampu untuk memproduksi maksimum 120 ton beras. Produksi beras ini dijual dengan harga yang berbeda untuk setiap konsumennya, tetapi Yanee Lasahido mengatakan bahwa rata-rata harga yang wajar adalah Rp. 6,000 .

Maka perhitungan kasar yang dapat kitaperkirakan adalah sebagai berikut: 5 x 120,000 kg x Rp, 6,000 = Rp. 3,600,000,000

Namun demikian, saat ini pabrik-pabrik tersebut baru mampu untuk memproduksi sekitar 40 ton per bulan. Maka akan kita dapatkan hasil penjualan kasar sebagai berikut:

5 x 40,000 kg x Rp. 6,000 = Rp. 1,200,000,000. 


\section{SIMPULAN}

Dari yang dicontohkan oleh PT. SAKTI PERSADA RAYA, dapat dilihat bahwa Business Model merupakan sebuah deskripsi kerja yang meliputi hal-hal umum secara detil terkait dengan operasional bisnis. Komponen-komponen yang terkandung di dalam sebuah Business Model diantaranya meliputi produk atau jasa, konsumen yang potensial, faktor pemasaran dan keuangan. Apabila digariskan secara umum, Business Model meliputi hal-hal yang terkait dengan operasional bisnis sehari-hari.

Dari contoh yang dipaparkan dalam Business Model PT. SAKTI PERSADA RAYA, dapat disimpulkan bahwa perusahaan ini merupakan sebuah perusahaan yang bergerak dalam industri produksi dan distribusi beras dengan menerapkan strategi pemanfaatan infrastruktur dan peralatan sederhana namun dengan investasi yang ditanamkan di berbagai daerah. Dengan hal ini, PT. SAKTI PERSADA RAYA optimis untuk dapat bersaing dalam kapasitas dan kualitas produksi dengan perusahaan-perusahaan besar lain dan dengan biaya investasi yang tidak terlalu besar.

Dalam pelaksanaannya, PT.SAKTI PERSADA RAYA terus menggali competitive advantages dan teknologi yang lebih baik untuk mendapatkan cost effectiveness dan profit margin yang lebih tinggi. Di masa yang akan datang, PT. SAKTI PERSADA RAYA berharap untuk dapat memiliki pabrik dan lahan produksi beras yang lebih banyak sekaligus mengangkat derajat para penyedia supply gabah yang terdiri dari para petani lokal.

\section{DAFTAR PUSTAKA}

Essentials, H. B. (2005). Entrepreneur's Toolkit: Tools and Techniques to Launch and Grow Your New Business. Harvard Business Review Press.

McInnis, D. (2011, March 3). Marketing Blog for Small Business. Retrieved February 16, 2012, from http://www.daniellemacinnis.com/marketing-training/why-is-it-important-to-have-a-business$\underline{\text { model/ }}$

Nesheim, J. (2009, 07 13). Nesheim Online. Retrieved 02 16, 2012, from

http://nesheimgroup.typepad.com/my_weblog/2009/07/startup-business-models-what-are-they-whyare-they-importan-t.html 